\title{
OPEN INNOVATION: SYSTEMATISATION OF KNOWLEDGE EXPLORATION AND EXPLOITATION FOR COMMERCIALISATION
}

\author{
CHRISTIAN TABI AMPONSAH ${ }^{*, *}$ and SAMUEL ADAMS ${ }^{\dagger}$ \\ *Skyline University College, School of Business and Management \\ P.O. Box: 1797, Sharjah, UAE \\ ${ }^{\dagger}$ Ghana Institute of Management and Public Administration \\ School of Public Service and Governance, Accra, Ghana \\ tchris_tabi@hotmail.com
}

Published 26 October 2016

\begin{abstract}
This paper explores the intricacies of various determinants that can be used to systematise open innovation processes as the functional streaming of knowledge, both inbound and outbound, to expedite internal innovation and extricate the market for external use of innovation. Drawing on extant open innovation literature and data collected from organisations on the list of Thomas Reuters Derwent World Patents Index covering North America, Europe, Asia, Sub-Saharan Africa, the Middle East and North African for their open innovation practices, a model was developed that conceptualises the systematisation of open innovation processes toward commercial activities. The results show that the systematisation of open innovation requires a balancing act of knowledge exploration (KET) and exploitation (KEL) ambidexterity for commercialisation of the firm, and that a relationship exists between these variables. Using the contingency-based approach to organisational development, the paper adds to the understanding of the role of open innovation processes, systematisation, content and context as well as the research and development aspect of open innovation.
\end{abstract}

Keywords: Ambidexterity; commercialisation; knowledge exploration; knowledge exploitation; open innovation; systematisation.

\section{Introduction}

The concept of open innovation has attracted much attention from management researchers from a variety of theoretical perspectives. However, open innovation has

${ }^{\ddagger}$ Corresponding author. 
been mostly investigated from the organisational level, while the antecedents, processes and outcomes on the other levels remain relatively unexplored. Traditionally, industrial firms depend on internal knowledge (closed innovation) to develop and nurture ideas inside the company until they are launched as new products or businesses. Open innovation allows ideas to flow in and out of an organisation through what can be described as porous boundaries (Vanhaverbeke, 2005; Chesbrough, 2003). Used first by Chesbrough (2003, p. 24), the term open innovation suggests that "firms can and should use external as well as internal ideas and paths to market as they look to advance their technology". The concept is used to describe innovation processes in which firms interact extensively with their environment, leading to a significant amount of external knowledge (EK) exploration (KET) and exploitation (KEL). To link open innovation framework to related literature, Lichtenthaler (2011, p. 77) proposes an expanded definition of open innovation, as "systematically performing KET, retention and exploitation inside and outside an organization's boundaries throughout the innovation process".

Historically, this interchange of knowledge with organisations or individuals that are not employed by the focal firm has been at the core of open innovation. Chesbrough (2006a) and Gaule (2006) posit that there is a general demand for companies to adopt this new way of thinking in order to exploit trends such as the increasing availability and mobility of skilled workers, the growth of venture capital and the rising quality of suppliers together with trends that erode the advantages of closed innovation.

In recent times, the strategy of open innovation has been used across industries with firms increasingly acquiring external technologies to complement their internal knowledge bases (for example, by means of strategic alliances or in-licensing, which involves acquiring the right to use EK (Beamish and Lupton, 2009; Cassiman and Veugelers, 2006; Teece, 1986; von Hippel, 1998). Similar developments have been observed in KET and KEL, whereby firms across industries actively commercialise their technological knowledge, either exclusively or in addition to using it internally for their own products by means of out-licensing or strategic alliances, thereby allowing external partners the use of their technology.

Despite its growing importance, many firms experience severe challenges in actively managing the processes of open innovation (Lichtenthaler, 2008a; van de Vrande et al., 2009), although there is evidence to show that pioneering companies, such as Procter \& Gamble, Cisco, DuPont, Philips, Apple, Samsung, Motorola, Hewlett Packard, Xerox, Unisys and Eli Lilly have achieved great benefits from the open innovation construct (Hacievliyagil et al., 2007; Huston and Sakkab, 2006; Schwartz and Huff, 2010; Schumpeter, 2002).

Additionally, the most successful firms had to overcome major challenges at the beginning of their open innovation initiatives (Chesbrough, 2007; Laursen and 
Salter, 2006), and there are major inter-firm differences in how open innovation is successfully managed. However, there has not been much research to systematise the open innovation process across organisations by adding value to the existing work of exploring knowledge for organisational development. Thus, practitioners and academics alike need a better understanding of open innovation processes in order to grasp the benefits while avoiding potential pitfalls rather than a trial and error approach (Gassmann and Enkel, 2004). Gassmann et al. (2010), for example, have suggested the need for researchers to develop a multilevel conceptual framework for organising open innovation in firms. Similarly, many of the studies on open innovation provide general prescriptions and do not take into consideration many contexts and contingencies that influence the innovation process (Tidd, 2014a).

Accordingly, this study contributes to the literature by exploring the determinants for systematising the open innovation process. The objective is to examine how systematisation of a firm's external KET and KEL processes influence the firm's commercialisation activities and overall performance. Although exploration and exploitation may compete for resources and that there are trade-offs between the two (Lavie et al., 2010), we follow prior research and argue that exploratory and exploitative innovation can be pursued simultaneously at the organisational level (Bierly and Daly, 2007; Cao et al., 2009; Gupta et al., 2006).

The systematisation of the commercialisation process provides an appropriate means of integrating the exploration and exploitation process and consequently, helping to achieve the right balance between the two as it relates to the sector, firm structure and strategy (Lichtenthaler, 2011). To do this effectively, the study employs the structural equation model (SEM) that takes in to account measurement problems, especially, as they relate to latent variables. In the sections that follow, a brief overview of the open innovation literature is given after which the methodology is described, the results are discussed, implications and conclusions given and directions for future research offered.

\section{Literature Review}

In this section, we present a brief overview of the open innovation paradigm and the hypotheses for the study.

\section{Open innovation paradigm}

In recent times, firms have been encouraged to employ open innovation to overcome challenges associated with increased competition and shorter product life 
cycles (Chesbrough, 2003). As firms become more permeable to the external environment, they gain benefits in terms of their ability to use the technology developed by others and vice versa (Cassiman and Valentini, 2009). Chesbrough (2003, pp. 36-37) puts it succinctly when he states that "open innovation allows firms to commercialize external ideas by deploying outside pathways to the market". The importance of the external source in open innovation is based on the assumption that the innovator for a particular product does not need to be the manufacturer of the product. In other words, any agent that derives benefits from an innovative product can also be a source of innovation (Hacievliyagil et al., 2007). Accordingly, firms who embrace open innovation are able to scale down internal research and development resources, while expanding the scope of their innovation activities to improve organisational performance.

Ozman (2011) claims that firms that employ open innovation strategies have the potential to increase their market share directly by increasing the number of participants in the market. Even more important is the opportunity for network externalities, especially in multi-layered markets. In light of the many benefits of open innovation, Roijakkers et al. (2014) assert that open innovation projects and strategies provide strong incentives for organisational growth and development. By opening their doors and integrating EK bearers (Kang and Kang, 2009) companies' can cope with shorter innovation cycles, rising R\&D costs and inadequate resources (Gassmann and Enkel, 2004; Piller and Hilgers, 2008).

Empirically, Mention and Asikainen (2012) examine the effects of open innovation on performance at the firm level and find that simultaneous cooperation and information sourcing from and to competitors reduce innovation expenditures and shorten the time to market for novelties. Similarly, Scott and Chaston (2013) investigate the effect of Peruvian firms engaged in open innovation and report that firms that employed open innovation systems enjoyed higher sales growth. Mowery (2009) and Trott and Hartmann (2009), however, argue that there is nothing new about the open innovation concept, and consequently, describe open innovation as old wine in new bottle. Trott and Hartmann (2009), in particular, assert that the open innovation concept is merely a repackaging and representation of what is already known in management and innovation literature. Indeed, more than three decades ago, Allen (1983) described the collaborative process between rival firms or market participants in sharing information and the development of new technologies as collective invention. Tidd (2014b) alludes to the popularity of the open innovation concept but criticised it for being too vague and prescriptive. In view of the limitations of the open innovation concept, Dabrowska et al. (2013) argue that it should be seen as a corporate philosophy rather than an activity performed by an organisation. 
Further, Trott and Hartmann (2009) claim that Chesbrough (2003) creates a false dichotomy in the argument that open innovation is the only alternative to closed innovation. The authors examine the six principles of open innovation to show that the paradigm creates a partial perception of what is true in itself but false in conveying the wrong impression that firms follow these ideas in recent times.

Empirical findings by Hacievliyagil et al. (2007) show that though in many instances firms may open up the flow of knowledge, the internal boundaries are tightened. Cassiman and Valentini (2009) also examine the argument that firms that employ open innovative systems are active in both the buying and selling market for technology and did not find support for this hypothesis for Belgian firms. Cassiman and Valentini (2009) find that the research and development productivity for firms active in selling, buying technology or doing both is not significantly different. This gives credence to the idea that open innovation paradigm overlooks the importance of research and technology transfer and absorptive capacity (Trott and Hartmann, 2009). These findings support the view that open innovation discussion should not just focus on accessing technology (Bigliardi et al., 2012) but also on research and development to deepen our understanding of how firms can maximise the benefits of technology acquired externally (Cohen and Levinthal, 1990).

\section{Hypotheses development}

Open innovation systematisation allows firms to clearly define, capture and document key learning and experiences with the purpose of transferring and adapting knowledge for commercialisation (UNDP, 2013). In this regard, systematisation helps to facilitate institutional review and learning resulting from projects to contribute to institutional decisions and changes encouraging more open and insightful organisational development. Accordingly, systematisation that helps to establish what is to be achieved, who is to do it and how to do it could reduce substantially the variance associated with the task (Gilson et al., 2005; March, 1991). Additionally, systematic processes and structures create a climate of goodwill that promotes creativity and knowledge (Koskinen et al., 2003; Madhavan and Grover, 1998). Lichtenthaler (2011), for example, has argued that managers may try to build on a firm's existing organisational processes and structures rather than implementing entirely new open innovation processes to avoid excessive initial learning periods. In an earlier study, Lichtenthaler (2008b) claims that the quality of the KET and KEL process drive the commercialisation and therefore performance of the open innovation activity. Obviously, being systematic enhances predictability and certainty in decision making. According to 
Lichtenthaler (2011), the increased predictability promotes trust within and outside the organisation and particularly among the project and product development teams. Thus, the systematisation of knowledge is critical for both exploration and exploitative activities of the firm. In a related study, Tidd et al. (2001) assert that the degree of systematic management routines is a key determinant of the commercialisation activity. Further, Frishammar et al. (2012) argue that the key to successful firm performance is contingent to commercialisation of firms' control processes. Prior literature adduce the fact that process innovation focuses on reaping efficiency gains by means of cost reductions and increased production volumes (Frishammar et al., 2012) and, in the process, contributes extensively to the reduction in development times for products (Chesbrough, 2006a; Pisano, 1994, 1996).

Although, we acknowledge that exploration and exploitation may compete for resources and that there may be trade-offs between the two (Lavie et al., 2010), we follow prior research and argue that exploratory and exploitative innovation can be pursued simultaneously at the organisational level (Cohen and Levinthal, 1990; Cao et al., 2009; Gupta et al., 2006).

Accordingly, it is hypothesised that:

H1: The systematisation of a firm's KET processes is positively related to the firm's commercialisation activities.

$\mathrm{H} 2$ : The systematisation of a firm's KEL process is positively related to the firm's commercialisation activities.

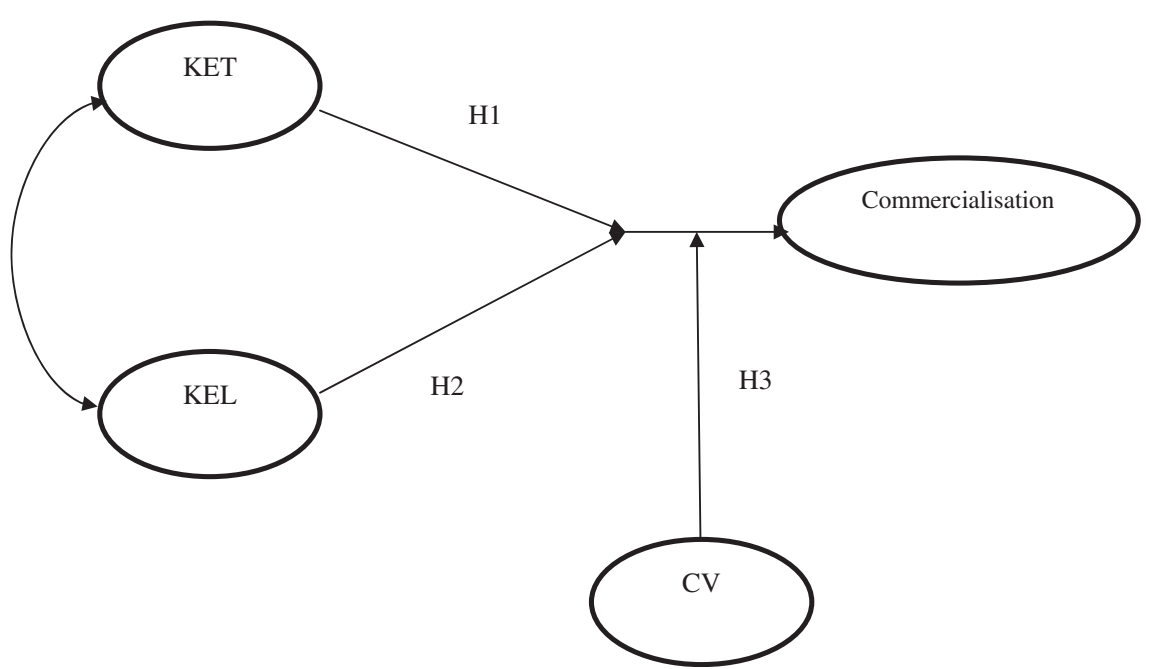

Fig. 1. Structural model for open innovation in a path diagram. 
H3: The commercialisation of a firm's control processes in knowledge systematisation affects firm's performance.

Figure 1 provides the structural model for open innovation in a path diagram based on the literature review taking in to account structural equation modelling.

The model is based on a contingency-based approach to organisational development (Burns and Stalker, 1961; Lawrence and Lorsch, 1967; Miller and Friesen, 1983) with the assumption that open innovation is used to tap EK and technology and putting it to use internally within firm. It is simultaneously aimed at commercialising internal knowledge and technology by finding new pathways to the external domain. Further, the main driver for switching between exploration and exploitation as alternative modes of learning is for the purposes of commercialisation. A concrete model with a concise framework addressing intellectual property issues, value capture, organisational culture and knowledge management would help organisations on a global scale to exploit ideas that are otherwise shelved due to uninformed markets (Meyer, 2009). Table 1 provides the variables and observed variables for the initial model.

Table 1. Latent variables and observed variables for initial model.

\begin{tabular}{|c|c|c|c|}
\hline $\begin{array}{l}\text { Latent variables/ } \\
\text { constructs }\end{array}$ & Observed variable/indicators & Abbreviations & References \\
\hline \multirow[t]{11}{*}{ KET } & Customer involvement & KET1 & $\begin{array}{l}\text { van de Vrande et al. (2009); } \\
\text { Thomke and von Hippel } \\
\text { (2002). }\end{array}$ \\
\hline & Technology solution & KET2 & Gassman (2006). \\
\hline & External networking & KET3 & $\begin{array}{l}\text { Chesbrough and Crowther } \\
\text { (2006). }\end{array}$ \\
\hline & External participation & KET4 & $\begin{array}{l}\text { Chesbrough (2006) Van de } \\
\text { Vrande } \text { et al. (2009) }\end{array}$ \\
\hline & Outsourcing R\&D & KET5 & $\begin{array}{l}\text { Gassman (2006); Prencipe } \\
\text { (2000); Chesbrough } \\
\text { (2006a). }\end{array}$ \\
\hline & Intellectual property & KET6 & Chesbrough (2006b). \\
\hline & Seeking opportunity & KET7 & Fetterhoff and Voelkel \\
\hline & Evaluating potential markets & KET8 & (2006). \\
\hline & Recruiting potential partners & KET9 & \\
\hline & Value capture & KET10 & \\
\hline & Extending innovation offer & KET11 & \\
\hline \multirow[t]{2}{*}{ KEL } & Customer utility & KEL1 & Fetterhoff and Voelkel \\
\hline & Competition & KEL2 & (2006). \\
\hline
\end{tabular}


Table 1. (Continued)

\begin{tabular}{|c|c|c|c|}
\hline $\begin{array}{l}\text { Latent variables/ } \\
\text { constructs }\end{array}$ & Observed variable/indicators & Abbreviations & References \\
\hline \multirow{10}{*}{$\begin{array}{l}\text { Commercialisation } \\
\qquad(\mathrm{COM})\end{array}$} & Commerce & KEL3 & \\
\hline & Capital & KEL4 & \\
\hline & Copyright & KEL5 & \\
\hline & Company fit & KEL6 & \\
\hline & Licensing sales and revenue & COM1 & \multirow{2}{*}{$\begin{array}{l}\text { Chesbrough (2003); Kline } \\
\text { (2003). }\end{array}$} \\
\hline & $\begin{array}{l}\text { Successful relationship with } \\
\text { client and competitors }\end{array}$ & COM2 & \\
\hline & Planning & COM3 & \multirow{4}{*}{$\begin{array}{l}\text { Reid et al. (2001); Escher } \\
\text { (2003). }\end{array}$} \\
\hline & Intellectual property & COM4 & \\
\hline & Negligence & COM5 & \\
\hline & Realisation & COM6 & \\
\hline \multirow[t]{7}{*}{ Control (CV) } & Venture capital & CV1 & $\begin{array}{l}\text { Dyer et al. (2001); Hoffmann } \\
\text { (2005). }\end{array}$ \\
\hline & $\mathrm{R} \& \mathrm{D}$ & $\mathrm{CV} 2$ & $\begin{array}{l}\text { Hacievliyagil et al. (2007); } \\
\text { Pisano }(1994,1996) .\end{array}$ \\
\hline & Commercialisation & CV3 & $\begin{array}{l}\text { Frishammar and Horte } \\
\text { (2005); Frishammar et al. } \\
\text { (2012). }\end{array}$ \\
\hline & Information need & CV4 & \multirow{4}{*}{$\begin{array}{l}\text { Lichtenthaler (2005). } \\
\text { Makhija and Ganesh (1997); } \\
\text { Hoffmann (2005). }\end{array}$} \\
\hline & Information generation & CV5 & \\
\hline & Information evaluation & CV6 & \\
\hline & Information control & CV7 & \\
\hline
\end{tabular}

\section{Methodology}

\section{Data collection}

Data was collected employing survey questionnaire methodology in order to resolve, refine and adjust the model described and shown in Fig. 2. The questionnaire was designed using guidelines outlined by Dillman (1991). The questions were based on the theoretical framework as indicated in Table 1. The questionnaire consisted of two sections, the first was devoted to demographic characteristics and the second, a brief and straight to-the-point questions addressing the factors measured by multiple questions.

The documents was set out in-line with the four sections and sub-sections, namely, KET, KEL, commercialisation and the controls. A five-point Likert scale was administered with " 1 " corresponding to strongly disagree and " 5 " being strongly agreed. 


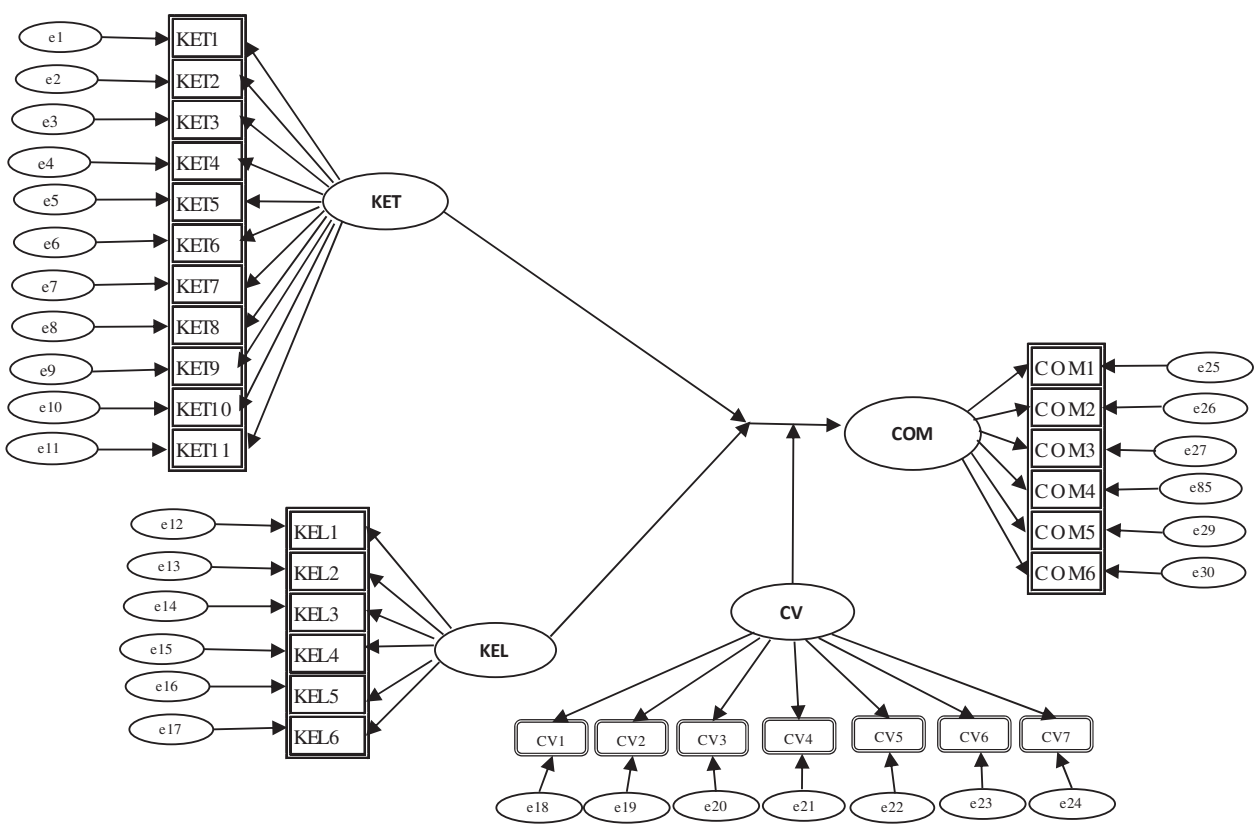

Fig. 2. Initial SEM for open innovation.

Prior to formal administration of the survey, a panel of five experts comprising of two senior academicians and three experienced practitioners from industry were used to solicit their opinions and assess the contents of the questionnaire. Some questions were rephrased for respondents to gain better understanding and to eliminate (or minimise as much as possible) the response bias. Revisions were then made to further refine the survey instrument. Thereafter, the refined questionnaire was considered an adequate instrument for the survey and was administered as such. The questionnaire was crafted in English and only those who were well versed in English were asked to respond to avoid misinterpretation of the questions.

The control stage refers to the evaluation and control processes of KET and KEL. Prior research in to alliances has shown that there are many interdependencies between the control stage and the other process stages, particularly planning and intelligence (Dyer et al., 2001; Hoffmann, 2005). Similar to intelligence, proficient control processes comprise the identification of information needs, information generation, information evaluation and information communication (Frishammar and Hörte, 2005; Lichtenthaler, 2005). The identification of information needs is directed at delimiting the needs to facilitate successful control (Gerybadze, 1994). 


\section{T. Amponsah \& S. Adams}

Besides controlling the activities of the firm, attention has to be paid to the technology customer's contribution (Yan and Gray, 1994; Bozeman, 2000). After generating information (Makhija and Ganesh, 1997; Hoffmann, 2005), its relevance has to be determined. Apart from evaluating the information, this assessment leads to organisational learning (Lichtenthaler, 2003). Finally, the results are communicated, and a decision is taken whether the activities will be continued or whether particular technology transactions should be redirected or finished (Doz and Hamel, 1998; Hoffmann, 2005). As defined by Chesbough (2006a), open innovation occurs through exploitation of knowledge diffusion outside corporate R\&D. Hence, several key factors drive the diffusion of technology-based knowledge as well as customer insight. In many cases, there are surrogate indicators that demonstrate the dynamics of knowledge diffusion. The total amount of venture capital spent in a given market sector reflects the investment industry's belief in the business health within that sector.

The SEM was used due to its advantage of modelling open innovation dependencies and latent variables (Nachtigall et al., 2003). SEM assists in the estimation of multiple and interrelated dependence relationships, possess the ability to represent unobserved concepts in these relationships and account for measurement error (Hair et al., 2009). The interdependencies between factors of KET and KEL may be assessed by other methods like analytic network process (ANP). Nevertheless, one of the drawbacks of ANP is that complexity increases exponentially with the number of indicators and their interdependencies due to the numbers of pairwise comparisons while SEM does not have limitation on the number of variables. There is no difficulty in hypothesis testing in SEM because it takes the confirmatory approach rather than the exploratory approach. The point that needs attention is that with the analyses employing SEM, like the present study, statistical correlation or association does not prove causation or influence, but simply supports the logical or intuitive belief in their presence (Xiong et al., 2014).

\section{Sampling procedure and biases}

Participants were drawn from five geographical locations (North America, Europe, Asia, Sub-Saharan Africa, the Middle East and North African). Base on Thomas Reuters Derwent World Patents Index, seven industrial categories that is; aerospace and defence, ITC, automotive, home appliances, medical devices pharmaceutical/ biochemistry and semi-conductors were sourced and used for the study. The details of the demographic characteristics is shown in Table 2.

The objective of the study was to collect data on open innovation, bearing this requisite in mind, the respondents were selected on the basis of relevant field 
Table 2. Demographic characteristics of respondents.

\begin{tabular}{|c|c|c|c|}
\hline Characteristics & Category & Frequency $(N=164)$ & Percentage $(\%)$ \\
\hline \multirow[t]{6}{*}{ Geographical location } & North America & 44 & 27 \\
\hline & Europe & 36 & 22 \\
\hline & Asia & 39 & 24 \\
\hline & Sub-Sahara Africa & 24 & 15 \\
\hline & Middle East and & 21 & 13 \\
\hline & North African region & & \\
\hline \multirow[t]{4}{*}{ Age group } & $>45$ & 54 & 33 \\
\hline & $35-44$ & 62 & 38 \\
\hline & $25-34$ & 44 & 27 \\
\hline & $<24$ & 4 & 2 \\
\hline \multirow[t]{2}{*}{ Gender } & Male & 137 & 84 \\
\hline & Female & 27 & 16 \\
\hline \multirow[t]{3}{*}{ Educational background } & $\mathrm{PhD}$ & 45 & 27 \\
\hline & MSc & 66 & 40 \\
\hline & $\mathrm{BSc}$ & 53 & 33 \\
\hline \multirow[t]{2}{*}{ Work experience } & $>10$ year & 99 & 60 \\
\hline & $5-10$ years & 65 & 40 \\
\hline \multirow[t]{4}{*}{ Designation } & Operations manager & 42 & 26 \\
\hline & Innovations manager & 70 & 43 \\
\hline & R\&D manager & 23 & 14 \\
\hline & Project manager & 29 & 18 \\
\hline \multirow{7}{*}{$\begin{array}{l}\text { Industry (Thomas Reuters } \\
\text { Derwent World Patents } \\
\text { Index) }\end{array}$} & Aerospace and defence & 20 & 12 \\
\hline & ITC & 14 & 9 \\
\hline & Automotive & 40 & 24 \\
\hline & Home appliances & 32 & 20 \\
\hline & Medical devices & 12 & 7 \\
\hline & Pharmaceutical/biochemistry & 31 & 19 \\
\hline & Semi-conductors & 15 & 9 \\
\hline
\end{tabular}

experience (at least five years), current designation (must at least be working at managerial level or as a full-time practitioner) as well as educational background (must hold at least a Bachelor's degree).

From Table 2, participation from practitioners having experience of more than 10 years is evident. Since we required a sound educational background, $67 \%$ of the respondents were post-graduates whereas $43 \%$ of the total were managers involved in innovation management.

The automotive sector had the dominant role in the survey followed by the home appliance and pharmaceutical/biochemistry sectors. Although it is believed 
that managers provide reliable and objective data by relying on their own selfreports (Aronson et al., 2006; Lukas and Ferrell, 2000; Podsakoff and Organ, 1986), we take in to account related biases. Self-report data are most problematic for subjects which generate strong sentiments such as attitudes (Aronson et al., 2006; Cote and Buckley, 1987). Open innovation is a lesser emotional topic and thus less probable to be distorted by self-reports. Another issue is the social desirability bias that mostly leads to distorted results (Podsakoff and Organ, 1986). The nature of the present study shows no evidence of having been affected by social desirability.

\section{Results and Analysis}

\section{Sample size and response rate}

Out of 267, 196 forms were returned and 164 responses were considered valid for the analysis resulting in a response rate of $61.4 \%$. This response rate is deemed reasonable on the basis of the previously published similar studies (Chen et al., 2011; Dvir and Lechler, 2004; Xiong et al., 2014). As SEM is a large sample technique (Mainul et al., 2005), a sample of at least 200 is recommended for normally distributed data (Hox and Bechger, 1998). Notwithstanding, this study with a sample size of 164 subjects is in line with previously-published SEM studies that used sample sizes of less than 200. For example, Mainul et al. (2005) used 52 cases, Eybpoosh et al. (2011) used 166 cases, Chen et al. (2011) used 124 cases, Doloi et al. (2011) used 97 cases and Xiong et al. (2014) used 125 cases, while exceeding the minimum of 100 cases recommended by Bagozzi and Yi (2012). Additionally, the present study does not lack adequate statistical power according to the framework developed by MacCallum et al. (1996) who determined the minimum sample sizes to achieve sufficient statistical power for SEM analyses.

\section{Construct reliability}

Cronbach's reliability test was performed to assess the strength and adequacy of measurement model (Jin et al., 2007). A cut-off value of 0.70 was used for Cronbach's alpha coefficient to indicate the acceptable level of internal consistency. Table 3 shows the items measuring four finally obtained latent constructs of the final SEM and their corresponding indicators. As shown, the constructs were found to have values above 0.70 resulting in a high degree of reliability and were proved to be sufficiently reliable for analysis. Latent variables and observed variables were used for initial model. 
Table 3. Reliability test for the final model.

\begin{tabular}{|c|c|c|c|}
\hline $\begin{array}{l}\text { Latent variables/ } \\
\text { constructs }\end{array}$ & Observed variable/indicators & Abbreviations & $\begin{array}{c}\text { Cronbach's } \\
\text { alpha value }(\alpha)\end{array}$ \\
\hline KET & $\begin{array}{l}\text { Customer involvement, } \\
\text { Technology solution } \\
\text { External networking, } \\
\text { External participation, } \\
\text { Outsourcing R\&D } \\
\text { Intellectual property } \\
\text { Seeking opportunity } \\
\text { Evaluating potential markets } \\
\text { Recruiting potential partners } \\
\text { Value capture } \\
\text { Extending innovation offer }\end{array}$ & $\begin{array}{l}\text { KET1 } \\
\text { KET2 } \\
\text { KET3 } \\
\text { KET4 } \\
\text { KET5 } \\
\text { KET6 } \\
\text { KET7 } \\
\text { KET8 } \\
\text { KET9 } \\
\text { KET10 } \\
\text { KET11 }\end{array}$ & 0.8792 \\
\hline KEL & $\begin{array}{l}\text { Customer utility } \\
\text { Competition } \\
\text { Commerce } \\
\text { Capital } \\
\text { Copyright } \\
\text { Company fit }\end{array}$ & $\begin{array}{l}\text { KEL1 } \\
\text { KEL2 } \\
\text { KEL3 } \\
\text { KEL4 } \\
\text { KEL5 } \\
\text { KEL6 }\end{array}$ & 0.801 \\
\hline $\begin{array}{l}\text { Commercialisation } \\
(\mathrm{COM})\end{array}$ & $\begin{array}{l}\text { Licensing sales and revenue } \\
\text { Successful relationship with } \\
\quad \text { client and competitors } \\
\text { Planning } \\
\text { Intellectual property } \\
\text { Negligence } \\
\text { Realization }\end{array}$ & $\begin{array}{l}\text { COM1 } \\
\text { COM2 } \\
\text { COM3 } \\
\text { COM4 } \\
\text { COM5 } \\
\text { COM6 }\end{array}$ & 0.762 \\
\hline Control (CV) & $\begin{array}{l}\text { Venture capital } \\
\mathrm{R} \& \mathrm{D} \\
\text { Commercialisation } \\
\text { Information need } \\
\text { Information generation } \\
\text { Information evaluation } \\
\text { Information control }\end{array}$ & $\begin{array}{l}\text { CV1 } \\
\text { CV2 } \\
\text { CV3 } \\
\text { CV4 } \\
\text { CV5 } \\
\text { CV6 } \\
\text { CV7 }\end{array}$ & 0.892 \\
\hline
\end{tabular}

The SEM as shown in Fig. 2 was analysed using the statistical computer program AMOS version 21. The questionnaire contained 30 variables as mentioned in detail in Table 1 representing five latent variables. In order to achieve a reliable final model and be compatible with the SEM framework, appropriate variables have to be selected from this list. Pearson product-moment coefficient of correlation analysis was performed to analyse variable correlations in the model. 


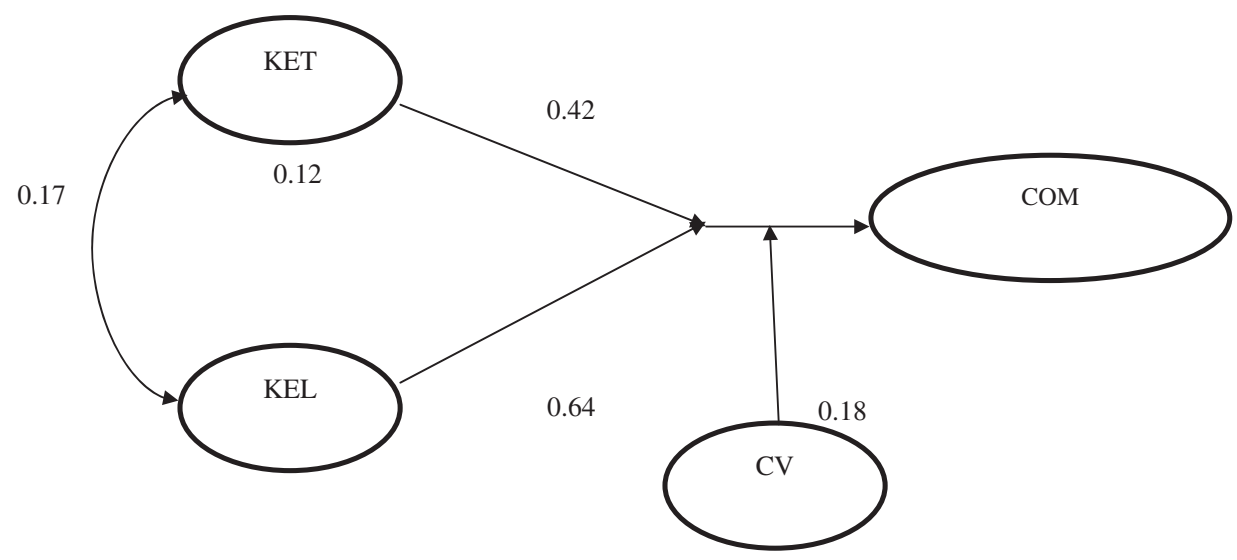

Fig. 3. Final structural model showing the insignificant paths.

At $95 \%$ confidence interval, variables showing insignificant associations with other variables within a latent construct and with other variables across the entire initial SEM were finally excluded from the model (Doloi et al., 2011; Mainul et al., 2005). Figure 3 illustrates the final structural model showing the paths.

The process was essential for the maturity of the model because the initial model that was based on theoretical expectations and past empirical findings was found to be premature without meeting the standard indices of model fit (Molenaar et al., 2000). Table 4 indicates the comparison of goodness-of-fit (GOF) indices of the initial and final SEM. After undergoing several iterations, the final model attains the recommended level of fitness and thus considered feasible for the analysis.

As displayed, the final model for commercialisation based on the necessary GOF measures is appropriately supported. The $\chi^{2} /$ degree of freedom ratio, giving

Table 4. Comparison of GOF measures of initial and final models.

\begin{tabular}{|c|c|c|c|}
\hline GOF & $\begin{array}{l}\text { Recommended levels of GOF measures } \\
\text { Source: Molenaar et al. (2000) } \\
\text { and Ong and Musa (2012) }\end{array}$ & Initial model & Final model \\
\hline$x^{2}$ degree of freedom & $<5$ & 6.12 & 2.5 \\
\hline Absolute fit RMSEA & $<0.1$ & 0.10 & 0.078 \\
\hline \multicolumn{4}{|l|}{ Incremental fit } \\
\hline CFI & 0 (no fit) to 1 (perfect fit) & 0.51 & 0.81 \\
\hline TLI & 0 (no fit) to 1 (perfect fit) & 0.44 & 0.80 \\
\hline \multicolumn{4}{|l|}{ Parsimonious fit } \\
\hline PFGI & $>0.5$ & 0.45 & 0.51 \\
\hline PNFI & $>0.5$ & 0.42 & 0.59 \\
\hline
\end{tabular}


a value of 2.5, indicates acceptable fit to the data. The value of the absolute fit parameter, root mean square error of approximation (RMSEA), is 0.078 which is below the recommended cutoff level of 0.10 . The two incremental fit parameters, namely, comparative fit index (CFI) and Tucker-Lewis index (TLI) give values of 0.81 and 0.80 , respectively, which also makes obvious the acceptable model fit. Parsimonious GOD index (PGFI) and parsimonious normal-fit index (PNFI) values above 0.5 provide sufficient evidence that the fit between measurement model and data is acceptable.

Pearson correlation analysis was used to validate the interrelationships among the constructs of project complexity in the final model achieved (Fornell and Larcker, 1981). These correlations are presented in Table 5. Significant correlations among the factors of commercialisation supported the convergent validity of the conceptual model.

\section{Final SEM results and discussion}

The two-stage method was used to develop the SEM as followed by Xiong et al. (2014). Confirmatory Factor Analysis (CFA) provides the first step and demonstrates a satisfactory GOF. This leads to the next (post-CFA) stage in which correlations between the latent variables are replaced with the hypothesised causal relationships as shown in Fig. 3.

Table 5. Construct correlations.

\begin{tabular}{lc}
\hline Constructs & Correlations \\
\hline KET $\leftarrow \rightarrow$ KEL & 0.173 \\
KET $\leftarrow \rightarrow$ CV & $0.41^{*}$ \\
KET $\leftarrow \rightarrow$ COM & $0.41^{*}$ \\
KEL $\leftarrow \rightarrow$ KET & 0.41 \\
KEL $\leftarrow \rightarrow$ CV & $-0.04^{\mathrm{a}}$ \\
$\mathrm{KEL} \leftarrow \rightarrow$ COM & 0.17 \\
$\mathrm{COM} \leftarrow \rightarrow$ KET & 0.18 \\
$\mathrm{COM} \leftarrow \rightarrow$ KEL & $0.47^{* *}$ \\
$\mathrm{COM} \leftarrow \rightarrow \mathrm{CV}$ & 0.27 \\
$\mathrm{CV} \leftarrow \rightarrow \mathrm{KET}$ & $0.008^{* * *}$ \\
$\mathrm{CV} \leftarrow \rightarrow \mathrm{KEL}$ & 0.67 \\
$\mathrm{CV} \leftarrow \rightarrow \mathrm{COM}$ & $-0.2^{\mathrm{a}}$ \\
\hline
\end{tabular}

Notes: Correlation of significant at: ${ }^{*} 0.1$ level, ${ }^{* *} 0.05$ level, ${ }^{* * *} 0.001$ level, ${ }^{\mathrm{a} I n s i g n i f i c a n t . ~}$ 


\section{The measurement component}

Table 6 shows measurement model estimates. The standardized regression weights are the measures of association of each observed variable to its corresponding latent variable.

Recruiting potential partners, value capture and extending innovation offer hierarchical levels and intellectual property have the most influence while EK,

Table 6. Measurement model estimates: standardized regression weights and SE.

\begin{tabular}{|c|c|c|c|c|c|c|}
\hline \multirow[t]{2}{*}{ Item } & \multicolumn{4}{|c|}{ Standardized regression weights } & \multirow[t]{2}{*}{ SE } & \multirow[t]{2}{*}{$t$-value } \\
\hline & KET & KEL & $\mathrm{COM}$ & $\mathrm{CV}$ & & \\
\hline KET1 & 0.890 & & & & 0.15 & 2.882 \\
\hline KET2 & 0.785 & & & & 0.14 & 3.587 \\
\hline KET3 & 0.424 & & & & 0.13 & 3.541 \\
\hline KET4 & 0.540 & & & & 0.014 & 5.423 \\
\hline KET5 & 0.705 & & & & 0.16 & 5.410 \\
\hline KET6 & 0.734 & & & & 0.16 & 5.900 \\
\hline KET7 & 0.872 & & & & 0.16 & 5.680 \\
\hline KET8 & 0.786 & & & & 0.16 & 4.075 \\
\hline KET9 & 0.956 & & & & 0.15 & 16.620 \\
\hline KET10 & 0.964 & & & & 0.15 & 9.450 \\
\hline KET11 & 0.652 & & & & 0.05 & 8.320 \\
\hline KEL1 & & 0.880 & & & 0.05 & 18.600 \\
\hline KEL2 & & 0.416 & & & 0.06 & 11.966 \\
\hline KEL3 & & 0.930 & & & 0.05 & 10.243 \\
\hline KEL4 & & 0.718 & & & 0.06 & 9.756 \\
\hline KEL5 & & 0.874 & & & 0.07 & 13.429 \\
\hline KEL6 & & 0.810 & & & 0.06 & 12.563 \\
\hline COM1 & & & 0.780 & & 0.05 & 10.666 \\
\hline $\mathrm{COM} 2$ & & & 0.881 & & 0.04 & 11.450 \\
\hline COM3 & & & 0.416 & & 0.14 & 6.890 \\
\hline COM4 & & & 0.930 & & 0.13 & 7.540 \\
\hline COM5 & & & 0.718 & & 0.14 & 8.790 \\
\hline COM6 & & & 0.850 & & 0.06 & 4.670 \\
\hline CV1 & & & & 0.780 & 0.08 & 3.542 \\
\hline CV2 & & & & 0.842 & 0.06 & 11.680 \\
\hline CV3 & & & & 0.786 & 0.06 & 12.492 \\
\hline CV4 & & & & 0.940 & 0.11 & 4.943 \\
\hline CV5 & & & & 0.640 & 0.06 & 5.354 \\
\hline CV6 & & & & 0.760 & 0.12 & 5.642 \\
\hline CV7 & & & & 0.870 & 0.14 & 4.670 \\
\hline
\end{tabular}

Note: All factors are significant at $p<0.001$. 
technology solution and customer involvement have the least influence on KET. Similarly, KEL is greatly influenced by customer utility, copy right and competition whereas capital has the least influence. Successful relationship with clients and competitors show the most influence in commercialisation followed by licensing sales and revenue. Research and development show higher influence on the control side followed by information valuation with venture capital having the least influence.

\section{The structural component}

Discussing the hypotheses as proposed in Sec. 4 of this paper, the main research finding is that all three hypotheses are supported based on the information derived from the data collected from practitioners. Table 6 illustrates the measurement model estimates showing the standard regression weights and standard error (SE).

Figure 4 depicts the final model of the paths. As seen, all of the path coefficients are positive and significant at $p<0.001$ except one, illustrated in Table 7 . The final SEM results suggest that knowledge exploitation has a strong positive effect on commercialisation.

Besides this effect, it is evident that the control elements directly influence commercialisation with almost the same strength. Since literature did not provide sufficient evidence to establish a causal hypothesis between venture capital and

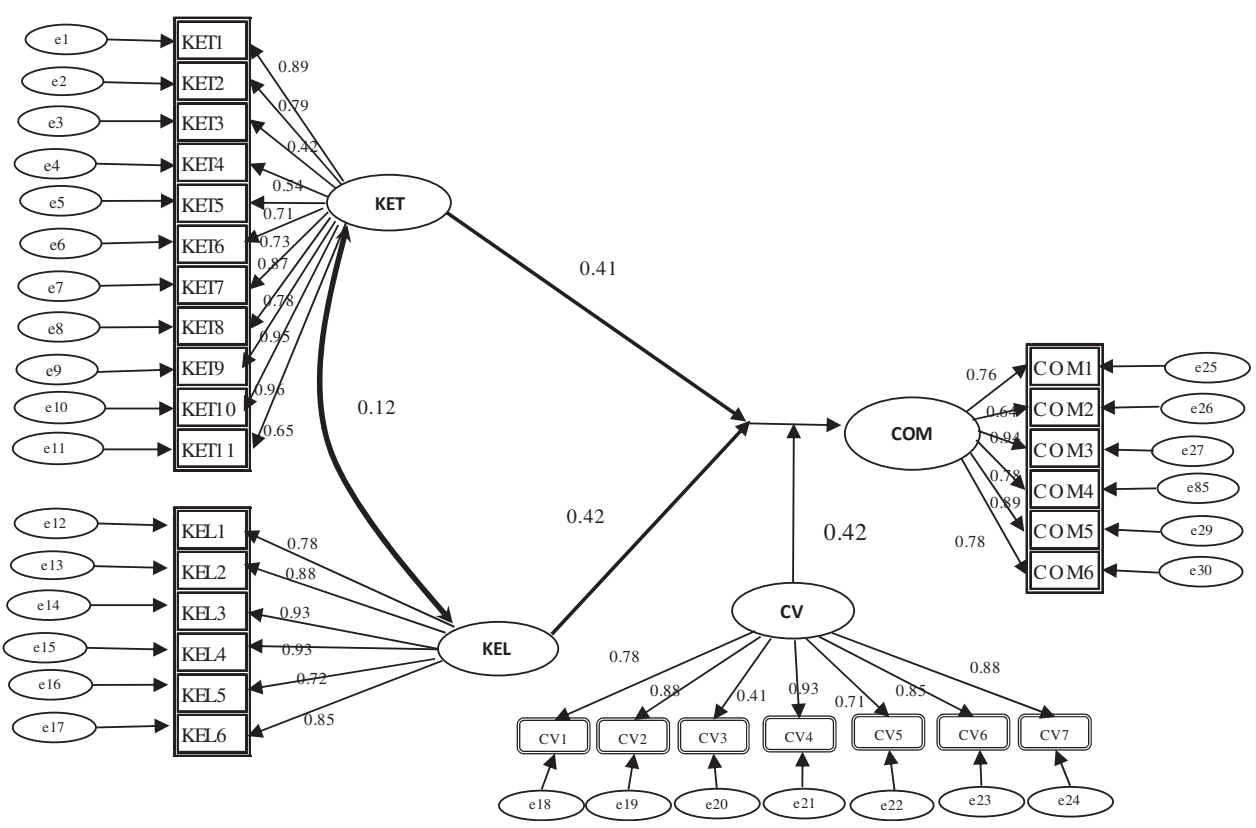

Fig. 4. Final SEM with all coefficient values. 
Table 7. Direct and indirect effects of structural model.

\begin{tabular}{lcccr}
\hline Path & Direct effect & Indirect effect & SE & $t$-value \\
\hline $\mathrm{KET} \rightarrow \mathrm{KEL}$ & $0.12^{\mathrm{a}}$ & - & 0.15 & 0.600 \\
$\mathrm{KET} \rightarrow \mathrm{COM}$ & 0.40 & - & 0.15 & 9.522 \\
$\mathrm{CV} \rightarrow \mathrm{COM}$ & 0.62 & - & 0.06 & 2.468 \\
$\mathrm{CV} \rightarrow \mathrm{KET}$ & 0.42 & - & 0.05 & 8.200 \\
$\mathrm{CV} \rightarrow \mathrm{KEL}$ & $-0.14^{\mathrm{a}}$ & - & 0.17 & -1.018 \\
$\mathrm{KET} \rightarrow \mathrm{CV} \rightarrow \mathrm{KEL}$ & - & 0.24 & & \\
\hline
\end{tabular}

Notes: All values are significant at $p<0.001{ }^{\text {a }}$ Insignificant.

value creation, the results in Table 7 indicate that knowledge exploitation and commercialisation are positively correlated with a standardized coefficient of 0.67 significant at $p<0.10$.

\section{Conclusions}

By crafting a model that systematises KET and KEL in open innovation, this paper adds to the understanding of the role of open innovation, process, systematisation, content and context as well as the research and development side of open innovation.

The study has numerous contributions to make to open innovation discourse. First, we extend discussions on open innovation and argue that systematisation of open innovation requires the balancing act of KET ambidexterity and exploitation for commercialisation of the firm, and that there is a mediated relationship between these variables. Second, by identifying the gap which mitigates the knowledge transfer through an organised medium in commercialising new ideas and technology thereby integrating the exploration and exploitation process, we provide a new threshold of insight that will help organisations widen the horizons of their technological arena. Third, the outcome of this study provides an understanding of the need for a business model which further streamlines the acceptance and institutionalising of open innovation process in organisations regardless of the size of the organisation. Fourth, the research helps explore the possibilities to minimise the issues of value capturing and intellectual rights. Fifth, the research sheds light on the importance of systematisation, values and attitudes on an individual-level, group-level and the organisation-level in adapting and implementing the open innovation process (de Jong et al., 2010).

Finally, the study provides insight in to how process innovation may add value directly to customers through improved product quality and reliability 
(Gopalakrishnan et al., 1999) and thus, lead to gains in effectiveness, advance a firm's competitive position and performance.

\section{Implications}

Our conclusions have several practical ramifications. Open innovation should not only be considered as a tool for absorbing useful input but integrating it in to the innovation process. Value capturing, knowledge management and protecting the intellectual property rights in an unbiased fashion, specifically focusing on integrating the various factors at an organisational level (including individual level and group level as propositions) in exploring and exploiting the EK.

By developing a business model to commercialise the external ideas as articulated by Majoor (2009), firms can investigate and substantiate the systematisation of the codification and sustaining the acquired EK to empower value capturing and intellectual property rights in implementing the open innovation process in their organisation.

Prior research has shown the importance of establishing a reputation as a knowledge provider in order to increase the monetary and strategic benefits of technology out-licensing (Lichtenthaler and Ernst, 2007). A third practice to benefit from internal knowledge is to capitalise on the initiatives and knowledge of current employees, including those who are not employed at the internal R\&D department. Several case studies illustrate that in formalities of employees with employees of other organisations are crucial to understand how new products are created and commercialised (Chesbrough and Crowther, 2006). Many practitioners and scientists, also outside the field of open innovation, endorse the view that innovation by individual employees is a means to foster organisational success (van de Ven, 1986). Work has also become more knowledge-based and is less rigidly-defined. In this context, employees can be involved in innovation processes in multiple ways, for example, by taking up their suggestions, exempting them to take initiatives beyond organisational boundaries, or introducing suggestion schemes such as idea boxes and internal competitions (van Dijk and van Den Ende, 2002).

Porter (1990) earlier justifiably posited that innovation is the bedrock of achieving competitive advantage, as such, the business environment has become more volatile, competitive and dynamic. As a result, increasingly more organisations are continuously looking for new ways of achieving innovation. Innovation speculates the replacement of an old concordance with a new paradigm within the bounds through a medium which establishes new horizons for exploring and exploiting technology and knowledge available both inside and outside the organisations. 


\section{Limitations and future research}

Many of the open innovation studies offer insights and propose various frameworks to support managerial decision making. Nevertheless, Gassmann et al. (2010) recently noted that the internal process by which companies manage open innovation is still more trial and error than a professionally-managed process. What is missing is a decent cookbook, an integrated framework that helps managers to decide when and how to deploy open innovation practices. Managers need to decide in what stage of the innovation process is collaboration most effective, and with which parties to collaborate, and how to find and select them. Decisions to be made also include selecting the best way to capture value in collaborative networks, especially when formal protection methods are less feasible, for example, with service innovations or small firms. These and many other issues require more systematic research.

Further research can also be carried out with a larger sample across more organisations from different industries and regions in order to obtain more validated information that can be analysed to draw conclusions on the various aspects and determinants of the open innovation process. Future research could also aim at testing the hypothesis: Accumulation of EK and its dissimilation positively impacts on the systematising of innovativeness in organisations. Once the determinants are succinctly established, the analytical hierarchy process can be used to determine further the critical success factors for systematisation and areas that organisations need to pay attention the most.

Finally, it is expected that this paper will spark a fruitful discourse on open innovation as well as related fields of organisational development and serve as stimulus for further research.

\section{References}

Allen, JE (1983). Recognizing intentions from natural language utterances. In Computational Models of Discourse, M Brady and RC Berwick, pp. 107-166. Cambridge, MA: MIT Press.

Aronson, ZH, RR Reilly and GS Lynn (2006). The impact of leader personality on new product development teamwork and performance: The moderating role of uncertainty The Journal of Engineering and Technology Management, 23, 221-247.

Bagozzi, RP and Y Yi (2012). Specification, evaluation, and interpretation of structural equation models. Journal of the Academy of Marketing Science, 40, 8-34.

Beamish, PW and NC Lupton (2009). Managing joint ventures. Academy of Management Perspectives, 23(2), 75-94.

Bierly, PE and PS Daly (2007). Alternative knowledge strategies, competitive environment, and organizational performance in small manufacturing firms, Entrepreneurship Theory and Practice, 31(4), 493-516. 
Bigliardi, B, AI Dormio and F Galati (2012). The adoption of open innovation within the telecommunication industry. European Journal of Innovation Management, 15(1), 27-54.

Bozeman, B (2000). Technology transfer and public policy: A review of research and theory. Research Policy, 29, 627-655.

Burns, T and GM Stalker (1961). The Management of Innovation. London: Tavistock.

Cao, Q, E Gedajlovic and H Zhang (2009). Unpacking organizational ambidexterity: Dimensions, contingencies, and synergistic effects. Organization Science, 20, 781-796.

Cassiman, B and G Valentini (2009). Strategic organization of R\&D: The choice of basicness and openness. Strategic Organization, 7(1), 43-73.

Cassiman, B and R Veugelers (2006). In search of complementarity in innovation strategy: Internal R\&D and external knowledge acquisition. Management Science, 52(1), 68-82.

Chen, YQ, YB Zhang, JY Liu and P Mo (2011). Interrelationships among critical success factors of construction projects based on the structural equation model. Journal of Management in Engineering, 28, 243-251.

Chesbrough, HW (2003). The era of open innovation, Sloan Management Review, 44(3), 35-41.

Chesbrough, H (2006a). Open innovation: A new paradigm for understanding industrial innovation. In Open Innovation: Researching a New Paradigm, H Chesbrough, W Vanhaverbeke, J West (Eds.), pp. 1-14. Oxford: Oxford University Press.

Chesbrough, HW (2006b). Open Business Models - How to Thrive in the New Innovation Landscape. Bostan, MA: Harvard Business School Press.

Chesbrough, H (2007). The market for innovation: Implications for corporate strategy. California Management Review, 49(3), 45-66.

Chesbrough, HW and AK Crowther (2006). Beyond high-tech: Early adopters of open innovation in other industries. $R \& D$ Management, 36(3), 229-236.

Cohen, WM and DA Levinthal (1990). Absorptive capacity: A new perspective on learning and innovation. Administrative Science Quarterly, 35, 128-152.

Cote, JA and MR Buckley (1987). Estimating trait, method, and error variance: Generalizing across 70 construct validation studies. Journal of Marketing Research, 24, 315-318.

Dabrowska, J, I Fiegenbaum and A Kutvonen (2013). Mapping the perception and reality of open innovation. International Journal of Innovation Management, 17(06), $134-156$.

de Jong, JJ, T Kalvet and W Vanhaverbeke (2010). Exploring a theoretical framework to structure the public policy implications of open innovation. Technology Analysis \& Strategic Management, 22(8), 877-896. doi: 10.1080/09537325.2010.522771.

Dillman, DA (1991). The design and administration of surveys. Annual Review of Sociology, http://arjournals.annualreviews.org [6, October 2014]. 
Doloi, H, K Iyer and A Sawhney (2011). Structural equation model for assessing impacts of contractor's performance on project success. International Journal of Project Managemaent, 29, 687-695.

Doz, YL and G Hamel (1998). Alliance Advantage: The Art of Creating Value through Partnering. Boston, MA: Harvard Business School Press.

Dvir, D and T Lechler (2004). Plans are nothing, changing plans is everything: The impact of changes on project success. Research. Policy, 33, 1-15.

Dyer, J, P Kale and H Singh (2001). How to make strategic alliances work. Sloan Management Review, 42(4), 37-43.

Escher, JP (2003). Design and implementation of technology marketing organizations. In Technology and Innovation Management on the Move, $\mathrm{H}$ Tschirky, $\mathrm{H}-\mathrm{H}$ Jung and $\mathrm{P}$ Savioz (Eds.), pp. 213-228. Zurich: Orell Füssli.

Eybpoosh, M, I Dikmen and M Birgonul (2011). Identification of risk paths in international construction projects using structural equation modeling. Journal of Construction Engineering and Management, 137, 1164-1175.

Fetterhoff, TJ and D Voelkel (2006). Managing open innovation in biotechnology. Research- Technology Management, 49(3), 14-18.

Fornell, C and DF Larcker (1981). Evaluating structural equation models with unobservable variables and measurement error. Journal of Marketing Research, 18, 39-50.

Frishammar, J and SA Horte (2005). Managing external information in manufacturing firms: The impact on innovation performance. Journal of Product Innovation Management, 22, 251-266.

Frishammar, J, M Kurkkio, L Abrahamsson and U Lichtenthaler (2012). Antecedents and consequences of firms' process innovation capability: A literature review and a conceptual framework. IEEE Transactions on Engineering Management, 59(4), $519-529$.

Gassman, O (2006). Opening up the innovation process: Towards an agenda. $R \& D$ Management, 36, 223-228.

Gassmann, O and E Enkel (2004). Towards a theory of open innovation: Three core process archetypes, Proc. R\&D Management Conf., pp. 1-18. July 6-9Lisbon, Portugal.

Gassmann, O, E Enkel and H Chesbrough (2010). The future of open innovation: $R \& D$ Management, 40(3), 213-221. doi: 10.1111/j.1467-9310.2010.00605.x.

Gaule, A. (2006). Open Innovation in Action: How to be Strategic in the Search for New Sources of Value. London, UK: H-I Network.

Gerybadze, A (1994). Technology forecasting as a process of organisational intelligence. $R \& D$ Management, 24(2), 131-140.

Gilson, LL, JE Mathieu, CE Shalley and TM Ruddy (2005). Creativity and standardization: Complementary or conflicting drivers of team effectiveness. Academy of Management Journal, 48, 521-531.

Gopalakrishnan, S, PE Bierly and EH Kessler (1999). A re-examination of product and process innovation using a knowledge-based view. Journal of High Technology Management Research, 10(1): 147-166. 
Gupta, AK, KG Smith and CE Shalley (2006). The interplay between exploration and exploitation. Academy of Management Journal, 49, 693-706.

Hacievliyagil, NK, YE Maisonneuve, J-F Auger and D Hartmann (2007). The positions of virtual knowledge brokers in the core process of open innovation. International Journal of Technology, Knowledge and Society, 3, 47-59.

Hair, JF, WC Black, BJ Babin and RE Anderson (2009). Multivariate Data Analysis. Upper Saddle River: Pearson International Edition.

Hoffmann, WH (2005). How to manage a portfolio of alliances. Long Range Planning, 38, $121-143$.

Hox, J and T Bechger (1998). An introduction to structural equation modeling. Family Science Review, 11, 354-373.

Huston, L and N Sakkab (2006). Connect and develop. Inside procter and gamble's new in the markets for knowledge, Research Policy, 36, 37-55.

Jin, XH, H Doloi and SY Gao (2007). Relationship-based determinants of building project performance in China. Construction Management and Economics, 25, 297-304.

Kang, KH and J Kang (2009). How do firms source external knowledge for innovation? Analysing effects of different knowledge sourcing methods. International Journal of Innovation Management, 13(01), 1-17.

Kline, D (2003). Sharing the corporate crown jewels. MIT Sloan Management Review, 44, 89-93.

Koskinen, KU, P Pihlanto and H Vanharanta (2003). Tacit knowledge acquisition and sharing in project work context. Int. J. Project Manage., 21(4), 281-290.

Laursen, K and A Salter (2006). Open for innovation: The role of openness in explaining innovation performance among U.K. manufacturing firms. Strategic Management Journal, 27, 131-150.

Lavie, D, U Stettner and ML Tushman (2010). Exploration and exploitation within and across organizations. The Academy of Management Annals, 4(1): 109-155.

Lawrence, P and J Lorsch (1967). Differentiation and integration in complex organizations. Administrative Science Quarterly, 12, 1-30.

Lichtenthaler, E (2003). Third generation management of technology intelligence processes. $R \& D$ Management, 33, 361-375.

Lichtenthaler, U (2005). External commercialization of knowledge: Review and research agenda. International Journal of Management Reviews, 7, 231-255.

Lichtenthaler, U (2007). Externally commercializing technology assets: An examination of different process stages, Journal of Business Venturing, 23(4), 445-464. doi: 10.1016/j.jbusvent.2007.06.002.

Lichtenthaler, U (2008a). Leveraging technology assets in the presence of markets for knowledge, European Management Journal, 26, 122-134.

Lichtenthaler, U (2008b). Open innovation in practice: An analysis of strategic approaches to technology transactions, IEEE Transactions on Engineering Management, 55(1), $148-157$. 
Lichtenthaler, U (2011). Open innovation: Past research, current debates, and future directions. Academy of Management Perspectives, 25(1), 75-93. doi: 10.5465/ AMP.2011.59198451.

Lichtenthaler, U and H Ernst (2007). Developing reputation to overcome the imperfections in the markets for knowledge, Research Policy, 36, 37-55.

Lukas, BA and O Ferrell (2000). The effect of market orientation on product innovation. Journal of the Academy of Marketing Science, 28, 239-247.

MacCallum, RC, MW Browne and HM Sugawara (1996). Power analysis and determination of sample size for covariance structure modelling. Psychological Methods, 1, 130-149.

Madhavan, R and R Grover (1998). From embedded knowledge to embodied knowledge: New product development as knowledge management. Journal of Marketing, 62(4), 1-12.

Mainul, F, M Islam and OO Faniran (2005). Structural equation model of project planning effectiveness. Construction Management and Economics, 23, 215-223.

Majoor, AJ (2009). Open innovation \& inside-out strategy: A research on organizational external intellectual assets commercialization capacity. Thesis, (MS) Utrecht University.

Makhija, MV and U Ganesh (1997). The relationship between control and partner learning in learning-related joint ventures. Organization Science, 5, 508-520.

March, JG (1991). Exploration and exploitation in organizational learning. Organizational Science, 2, 71-87.

Mention, A-L and AL Asikainen (2012). Innovation \& productivity: Investigating effects of openness in services. International Journal of Innovation Management, 16(3), 1-27.

Meyer, ZHS (2009). Exploring the global patent landscape: An information processing model. Thesis, Master's in Management, Copenhagen Business School.

Miller, D and PH Friesen (1983). Strategy-making and environment: The third link. Strategic Management Journal, 4, 221-235.

Molenaar, K, S Washington and J Diekmann (2000). Structural equation model of construction contract dispute potential. Journal of Construction Engineering and Management, 126, 268-277.

Mowery, DC (2009). Plus ca change: Industrial R\&D in the third industrial revolution. Industrial and Corporate Change, 18(1), 1-50.

Nachtigall, C, U Kroehne, F Funke and R Steyer (2003). Why should we use SEM? Pros and cons of structural equation modeling. Online, 8, 1-22.

Ong, TF and G Musa (2012). Examining the influences of experience, personality and attitude on SCUBA divers underwater behaviour: A structural equation model. Tourism Management, 33(6), 1521-1534.

Ozman, M (2011). Modularity, industry life cycle and open innovation. Journal of Perspectives, 23(2), 75-94.

Piller, F and D Hilgers (2008). Open innovation: externes wissen fu.r erfolgreiche innovations prozesse. RKW Magazin, 3, 12-13. 
Pisano, GP (1994). Knowledge, integration, and the locus of learning: An empirical analysis of process development, Strategic Management Journal, 15(1), 85-100.

Pisano, GP (1996). Learning-before-doing in the development of new process technology, Research Policy, 25(7), 1097-1119.

Podsakoff, PM and DW Organ (1986). Self-reports in organizational research: Problems and prospects. Journal of Management, 12, 531-544.

Porter, ME (1990). What is national competitiveness? Harvard Business Review, 68(2), 84-85.

Prencipe, A (2000). Breadth and depth of technological capabilities in CoPS: The case of the aircraft engine control system. Research Policy, 29(7-8), 895-911.

Reid, D, D Bussiere and K Greenaway (2001). Alliance formation issues for knowledgebased enterprises. International Journal of Management Reviews, 3, 79-100.

Roijakkers, N, J Bell, J Fok and W Vanhaverberke (2014). Open innovation through R\&D partnerships: Implementation issues and routes to success. In Open Innovation through Strategic Alliances, R Colpan (Ed.), pp. 41-58. New York: Palgrave MacMillan.

Schumpeter, JA (2002). The economy as a whole: Seventh chapter of the theory of economic development. Industry and Innovation, 9(1/2), 93.

Schwartz, K and B Huff (2010). The story of Eli Lilly's open innovation journey: How one company developed a mature model. PDMA Visions, pp. 19-22.

Scott, G and I Chaston (2013). Open innovation in an emerging economy. Management Research Review, 36(10), 1024-1036.

Teece, DJ (1986). Profiting from technological innovation: Implications for integration, collaboration, licensing and public policy. Research Policy, 15, pp. 285-305.

Tidd, J (2014a). Open Innovation Research, Management and Practice. Series on Technology Management, Vol. 23. London: Imperial College Press. ISBN 9781783262809.

Tidd, J (2014b). Introduction: Why we need a tighter theory and more critical research on open innovation. In Open Innovation Research, Management and Practice, Vol. 23, Tidd, J (ed.), pp. 1-10. Hackensack, NJ: World Scientific.

Tidd, JJ Bessant and K Pavitt (2001). Managing Innovation, Chichester: John Wiley \& Sons Ltd.

Thomke, S and E von Hippel (2002). Customers as innovators: A new way to create value. Harvard Business Review, 80, 74-80.

Trott, P and D Hartmann (2009). Why 'Open Innovation' is old wine in new bottles. International Journal of Innovation Management, 13(4), 715-736.

UNDP (2013). Knowledge Management Strategy Framework 2014-2017 http://www. undp.org/content/dam/undp/library/capacity-development/English/UNDP $\left[\begin{array}{ll}31 & \text { July }\end{array}\right.$ 2015].

van de Ven, AH (1986). Central problems in the management of innovation. Management Science, 32(5), 590-607. 
van de Vrande, V, JPJ de Jong, W Vanhaverbeke and M de Rochemont (2009). Open innovation in SMEs: Trends, motives and management challenges. Technovation, 29, 423-437.

van Dijk, C and J van Den Ende (2002). Suggestion systems: Transferring employee creativity into practicable ideas. $R \& D$ Management, 32, pp. 387-395.

Vanhaverbeke, W (2006). The inter-organizational context of open innovation. In Open Innovation: Researching a New Paradigm, WH Vanhaverbeke and J West (Eds.), pp. 205-219. Oxford: Oxford University Press.

von Hippel, E (1988). The sources of innovation. New York: Oxford University Press.

Xiong, B, M Skitmore, B Xia, MA Masrom, K Ye and A Bridge (2014). Examining the influence of participant performance factors on contractor satisfaction: A structural equation model. International Journal of Project Management, 32, 482-491.

Yan, A and B Gray (1994). Bargaining power, management control, and performance in US-China joint ventures: A comparative case study. Academy of Management Journal, 37(6), 1478-1517. 